\title{
Recent developments in viral load measurement in human herpesviruses
}

\author{
Guy Boivin MD
}

\begin{abstract}
G Boivin. Recent developments in viral load measurement in human herpesviruses. Can J Infect Dis 1999;10(Suppl C):33C-40C.

Recent developments in molecular biology have allowed precise quantitative analysis of herpesvirus DNA in many biological fluids. This paper reviews the clinical utility of performing quantitative polymerase chain reaction testing for herpesviruses. In particular, the assessment of the cytomegalovirus (CMV) DNA load in blood with regard to the development of CMV disease in immunocompromised patients is discussed in greater detail. Relevant information exists to support measuring the CMV burden in the blood of AIDS and transplant patients for diagnostic and treatment monitoring purposes, and, to a lesser extent, to envision the monitoring of the circulating Epstein-Barr virus load for the prevention of post-transplant lymphoproliferative disorders. On the other hand, there are controversial data on the clinical utility of measuring the herpes simplex virus (HSV) load in cerebrospinal fluid of patients with HSV encephalitis and on the relationship between the human herpesvirus 8 DNA load in diverse biological fluids and the presence of Kaposi's sarcoma. There is a paucity of information about the clinical impact of quantifying the other human herpesviruses (varicella-zoster virus, and human herpesviruses 6 and 7 ).
\end{abstract}

Key Words: Herpesviruses; Quantitative polymerase chain reaction; Viral load

\begin{abstract}
Avancées récentes dans la mesure de la charge virale des virus herpétiques humains
RÉSUMÉ : Des avancées récentes en biologie moléculaire ont permis de procéder à une analyse quantitative précise de l'ADN du virus de l'herpès dans de nombreux liquides biologiques. Le présent article passe en revue l'utilité clinique du test d'amplification en chaîne par polymérase (PCR) pour les virus de l'herpès, en particulier, l'appréciation de la charge d'ADN du cytomégalovirus (CMV) dans le sang relativement à l'évolution de la maladie à CMV chez les patients immunodéprimés est discutée plus amplement. Des données probantes existent en faveur d'une mesure de la charge du CMV dans le sang des patients atteints du SIDA et des patients greffés, pour des raisons de surveillance thérapeutique et diagnostique et, dans une moindre mesure, pour envisager la surveillance de la charge circulante du virus d'Epstein-Barr afin de prévenir les troubles lymphoprolifératifs survenant après une transplantation. D'autre part, il y a controverse sur les données concernant l'utilité clinique de mesurer la charge de l'herpès simplex virus (HSV) dans le liquide céphalo-rachidien des patients atteints d'encéphalite à HSV, et sur la relation entre la charge d'ADN du virus herpétique humain de type 8 dans divers liquides biologiques et la présence d'un sarcome de Kaposi. Il y a une pénurie d'informations sur l'impact clinique de la quantification des autres virus herpétiques humains (virus zona-varicelle (VZV) et virus herpétiques humains de types 7 et 8.
\end{abstract}

Centre de Recherche en Infectiologie du CHUL and Université Laval, Ste-Foy, Québec

This work was presented in part at the Canadian Infectious Disease Society Meeting, November 81998 , Toronto, Ontario Correspondence and reprints: Dr Guy Boivin, CHUL, room RC-709, 2705 blvd Laurier, Ste-Foy, Québec G1V 4G2. Telephone 418-654-2705, fax418-654-2715, e-mail guy.boivin@crchul.ulaval.ca 
$\mathrm{M}$ embers of the Herpesviridae family are large DNAcontaining, enveloped viruses (1). Eight of these viruses specifically infect humans. These viruses have been classified into three subfamilies (alpha, beta and gamma) based on host cell tropism and other biological properties (Table 1). The viral genome ranges from $125 \mathrm{~kb}$ (varicellazoster virus [VZV]) to $229 \mathrm{~kb}$ (cytomegalovirus [CMV]). Herpesvirus genomes contain two unique sequences (long and short) that are flanked by repeated DNA sequences (terminal and internal repeats). These internal regions can be inverted and lead to different isomeric forms. The replication of herpesviruses is highly regulated, first with the expression of immediate-early genes coding for regulatory proteins, followed by early genes (thymidine kinase, DNA polymerase). After DNA replication, the late structural genes coding for glycoproteins are expressed. One of the basic properties of herpesviruses consists of inducing lifelong latent infections in their natural hosts.

\section{HOW TO MEASURE THE HERPESVIRUS LOAD}

Following the development of methods to monitor the human immunodeficiency virus (HIV) load, scientists applied the same principles to the herpesviruses. The four major objectives in measuring the herpesvirus load are the following:

1. to establish or confirm the presence of disease (diagnosis);

2. to evaluate the risk of disease (pre-emptive strategy);

3. to monitor antiviral therapy;

4. indirectly to assess for the emergence of drugresistant strains.

One of the most critical initial steps in measuring the herpesvirus load consists of selecting the right sample for quantification. In other words, it is necessary to know about the active site of viral replication. Whenever possible, readily accessible sites such as blood or urine should be selected once it is suspected that viremia or viruria have occurred. The next step consists of choosing the right methodology (ie, nonmolecular versus molecular methods and detection based on target amplification versus signal amplification). It is important that key methodological variables be assessed, including sensitivity, specificity, predictive values, reproducibility (intraand interassay), lower limit of detection and dynamic range. Finally, after the type of samples and methodology are selected, the next step consists of determining the best viral load threshold or cutoff value associated with viral disease. The latter needs to be evaluated in prospective studies performed in different clinical settings.

There are many ways to evaluate the herpesvirus load; some methods are associated with poor standardization and reproducibility, and other methods have been well evaluated and are commercially available. To date, most quantitative methods have been developed and evaluated for the purpose of measuring the CMV viral load in blood. The characteristics of the nonmolecular and molecular methods for CMV quantifi-
TABLE 1

Classification and properties of human members of the Herpesviridae family

\begin{tabular}{|c|c|c|c|}
\hline Subfamily & Virus & $\begin{array}{l}\text { Genome } \\
\text { size }(\mathbf{k b})\end{array}$ & Type of infection \\
\hline \multirow[t]{3}{*}{ Alphaherpesvirinae } & Herpes simplex-1 & 152 & $\begin{array}{l}\text { Gingivostomatitis, } \\
\text { keratitis, } \\
\text { genital herpes, } \\
\text { encephalitis }\end{array}$ \\
\hline & Herpes simplex-2 & 152 & $\begin{array}{l}\text { Genital herpes, } \\
\text { meningitis, } \\
\text { neonatal herpes }\end{array}$ \\
\hline & Varicella-zoster & 125 & Varicella, zoster \\
\hline \multirow[t]{3}{*}{ Betaherpesvirinae } & Cytomegalovirus & 229 & $\begin{array}{l}\text { Mononucleosis, } \\
\text { hepatitis, } \\
\text { congenital disease, } \\
\text { retinitis, colitis, } \\
\text { pneumonitis }\end{array}$ \\
\hline & $\begin{array}{l}\text { Human } \\
\text { herpesvirus- } 6\end{array}$ & 165 & $\begin{array}{l}\text { Roseola, } \\
\text { encephalitis, } \\
\text { pneumonitis }\end{array}$ \\
\hline & $\begin{array}{l}\text { Human } \\
\text { herpesvirus-7 }\end{array}$ & $\sim 145$ & Roseola \\
\hline \multirow[t]{2}{*}{ Gammaherpesvirinae } & Epstein-Barr & 172 & $\begin{array}{l}\text { Mononucleosis, } \\
\text { hepatitis, } \\
\text { post-transplant } \\
\text { lymproproliferative } \\
\text { disorders }\end{array}$ \\
\hline & $\begin{array}{l}\text { Human } \\
\text { herpesvirus- } 8\end{array}$ & $\sim 140$ & $\begin{array}{l}\text { Kaposi's sarcoma, } \\
\text { cavity-based } \\
\text { lymphoma, } \\
\text { Castleman's } \\
\text { disease }\end{array}$ \\
\hline
\end{tabular}

TABLE 2

Characteristics of nonmolecular quantitative cytomegalovirus assays

\begin{tabular}{|c|c|c|c|}
\hline Assays & $\begin{array}{l}\text { Conventional } \\
\text { culture }\end{array}$ & p72 shell vial & $\begin{array}{c}\text { pp65 } \\
\text { antigenemia }\end{array}$ \\
\hline $\begin{array}{l}\text { Turnaround } \\
\text { time }\end{array}$ & 2 to 4 weeks & 18 to $48 \mathrm{~h}$ & $5 \mathrm{~h}$ \\
\hline Report of results & $\begin{array}{l}\text { Number of } \\
\text { PFUs, TCID } \\
50\end{array}$ & $\begin{array}{l}\text { Number of } \\
\text { infectious foci }\end{array}$ & $\begin{array}{c}\text { Number of } \\
\text { positive } \\
\text { cells } / 2 \times 10^{5} \mathrm{PBL}\end{array}$ \\
\hline $\begin{array}{l}\text { Lower limit of } \\
\text { detection }\end{array}$ & NA & NA & NA \\
\hline Dymamic range & NA & NA & NA \\
\hline Reproducibility & Low & Unknown & Relatively low \\
\hline Advantages & $\begin{array}{l}\text { Virus available } \\
\text { for susceptibility }\end{array}$ & $\begin{array}{l}\text { Used with } \\
\text { nonblood } \\
\text { samples }\end{array}$ & Rapidity \\
\hline Disadvantages & $\begin{array}{l}\text { Low sensitivity, } \\
\text { slow }\end{array}$ & $\begin{array}{l}\text { Low sensitivity, } \\
\text { toxicity }\end{array}$ & $\begin{array}{l}\text { Immediate } \\
\text { processing }\end{array}$ \\
\hline
\end{tabular}

NA Not available; PBL Peripheral blood leukocytes; PFU Plaque-forming unit; $T C I D_{50} 50 \%$ Tissue culture infecting dose

cation are summarized in Table 2 and Table 3 , respectively. Clinical applications of quantitative polymerase chain reaction (PCR) methods for selected human herpesviruses are reviewed next. 
TABLE 3

Characteristics of molecular quantitative cytomegalovirus (CMV) assays

\begin{tabular}{|c|c|c|c|}
\hline Characteristics & $\begin{array}{c}\text { Branched DNA assay } \\
\text { (Chiron Corporation, California) }\end{array}$ & $\begin{array}{c}\text { Hybrid capture DNA assay } \\
\text { (Digene Corporation, Maryland) }\end{array}$ & $\begin{array}{c}\text { PCR Amplicor } \\
\text { (Roche Diagnostics, New Jersey) }\end{array}$ \\
\hline Turnaround time & $24 \mathrm{~h}$ & $6 \mathrm{~h}$ & $6 \mathrm{~h}$ \\
\hline Report of results & $\mathrm{c} / \mathrm{mL}$ & $\mathrm{pg}$ of CMV DNA or $\mathrm{c} / \mathrm{mL}$ & $\mathrm{c} / \mathrm{mL}$ or $10^{5} \mathrm{PBL}$ \\
\hline Lower limit of detection & $9 \times 10^{2} \mathrm{c} / 10^{6} \mathrm{PBL}(2.0)$ & $7 \times 10^{2} \mathrm{c} / \mathrm{mL}(2.0)$ & 3 to $4 \times 10^{2} \mathrm{c} / \mathrm{mL}$ (quantitative) \\
\hline Dynamic range & $3 \log 10$ & $2 \log 10$ & 2 to $3 \log 10$ \\
\hline \multicolumn{4}{|l|}{ Reproducibility } \\
\hline Advantages & High reproducibility & Rapidity, simple processing & High sensitivity, batch testing \\
\hline Disadvantages & Large number of $\mathrm{PBL}$, slow & Tube format & PCR contamination (low probability) \\
\hline
\end{tabular}

c Copies; PBL Peripheral blood leukocytes; PCR Polymerase chain reaction

\section{HERPES SIMPLEX VIRUS LOAD}

Cerebrospinal fluid (CSF) and genital tract secretions are the main clinical samples used in quantitative herpes simplex virus (HSV) PCR studies. The detection of HSV DNA in CSF by PCR is considered to be the method of choice for the diagnosis of HSV encephalitis (2-4). Recently, there has been some interest in evaluating the HSV DNA load to assess the prognosis of HSV encephalitis. In a study by Domingues et al (5), the amounts of HSV DNA in CSF from individuals with HSV encephalitis ranged from less than 25 to 18,000 copies $/ \mu \mathrm{L}$ in CSF when obtained before or within four days of the initiation of therapy. More significantly, the authors reported a poorer clinical outcome for patients with a high viral DNA load in CSF (greater than 100 copies $/ \mu \mathrm{L}$ ). Such patients were more likely to have a reduced level of consciousness and cerebral lesions detected by a computed tomography scan. The same study also provides preliminary indications that HSV DNA load monitoring over time may help to assess patients' response to acyclovir. Indeed, in five of six individuals with serial CSF evaluations, HSV-1 DNA levels declined during acyclovir therapy. The only patient who had an increased HSV DNA load during therapy died on day 8 (5). In contrast, other investigators failed to demonstrate a clear correlation between the HSV-1 DNA burden in CSF and clinical outcome or radiological findings $(6,7)$. This has led investigators to speculate that indirect (immune-mediated) mechanisms may play a significant role in the development of cerebral pathology in individuals with HSV encephalitis. To date, there has been very limited information about the use of quantitative HSV PCR with swabs obtained from patients with genital lesions or asymptomatic genital shedding. Hobson et al (8) evaluated the HSV DNA content from swabs of genital secretions using quantitativecompetitive PCR. They showed that higher HSV DNA levels were shed when patients had genital lesions.

In summary, more studies need to be performed to resolve the conflicting data about the clinical value of performing quantitative PCR for HSV-1 in CSF during HSV encephalitis. Also, the utility of measuring the HSV-2 DNA burden for the management of genital herpes (ie, to assess antiviral efficacy and risk of transmission) requires further investigation.

\section{LOAD}

Following primary infection or during reactivation in immunocompromised patients, CMV can be shed in numerous body fluids, including urine, saliva, genital secretions and blood. Because CMV viremia is associated closely with CMV disease $(9,10)$, there has been considerable interest over the past years in monitoring the blood viral load in different clinical settings. In the HIV-infected population, CMV retinitis used to be a dreadful complication associated with a collapsed immune system (CD4 T cell counts less than $50 \times 10^{6} / \mathrm{L}$ ); many studies have confirmed the clinical utility of monitoring the circulating viral load to predict CMV retinitis. Bowen et al (11) showed that a positive CMV PCR result using whole blood was associated significantly with the development of disease, with a relative hazard of 20.15. Moreover, in PCR-positive patients, each $0.25 \log _{10}$ increase in viral load increased the risk of disease by 1.37 -fold. Similarly, Spector et al (12) demonstrated recently that each $\log _{10}$ increase in baseline CMV DNA load in plasma resulted in a 3.1-fold increase in risk of CMV disease and a 2.2 -fold increase in mortality. We and other investigators have shown that the mean number of CMV DNA copies in leukocytes of AIDS patients with CMV retinitis was 29- to 39fold higher than the viral load present in asymptomatic patients with low $\mathrm{CD} 4 \mathrm{~T}$ cell counts (less than $100 \times 10^{6} / \mathrm{L}$ ) $(13,14)$.

In a recent study, we sought to evaluate the clinical utility of quantitative versus qualitative PCR and the use of polymorphonuclear leukocytes (PMNLS) versus plasma for the diagnosis of CMV retinitis in HIV-infected patients (15). When the number of CMV copies in the two types of samples was normalized per $1 \mathrm{~mL}$ of whole blood, the CMV DNA burden was consistently higher in the PMNL fraction compared with plasma for both asymptomatic and symptomatic patients. The sensitivity, specificity, and positive and negative predictive values of qualitative PCR using PMNL to detect the presence of CMV disease were $100 \%, 58 \%, 38 \%$ and $100 \%$, respectively, compared with $70 \%, 93 \%, 74 \%$ and $92 \%$, respectively, for qualitative PCR-plasma and $93 \%, 92 \%, 76 \%$ and $98 \%$, respectively, for quantitative PCR-PMNL using a cutoff of 16,000 copies $/ \mathrm{mL}$ (or about 350 copies $/ 10^{5}$ PMNLs). Thus, the best strategy for 
diagnosing CMV disease in these individuals relies on the quantitative assessment of the viral DNA load in PMNLs. On the other hand, the use of plasma is more convenient and does not require quantification. However, the last option, although very specific, does not rule out the presence of disease in the case of a negative result (sensitivity of $70 \%$ ).

More recently, the monitoring of the blood CMV DNA load has been shown to be beneficial for enacting pre-emptive therapy in solid organ transplant (SOT) recipients. In patients with renal transplants, levels of CMV DNA exceeding 1000 copies $/ 10^{5}$ PMNLs in week 4 after transplantation are highly predictive of subsequent occurrence of symptomatic infections (16). In addition, patients with higher initial CMV DNA levels require a longer time to become PCR negative on initiation of ganciclovir therapy. The importance of the blood viral load in the pathogenesis of CMV disease was also demonstrated in liver transplant recipients (17). It is of interest that Cope et al (17) showed that the blood virus load and the total methylprednisolone dosage were the only independent risk factors for CMV disease in this population as assessed by a multivariate analysis. In the latter study, the donor-recipient CMV serological status was not an independent risk factor because it could be explained by an elevated virus load. Quantitative CMV PCR is also useful in heart allograft recipients where viral DNA levels at least 500 copies/ $1 \mu \mathrm{g}$ of total DNA from whole blood can be used to differentiate symptomatic CMV infections from other infections and rejection, although some overlap in levels may occur (18). We found that the CMV DNA load in leukocytes of bone marrow transplant (BMT) recipients with CMV disease was significantly lower than that in SOT recipients and HIV-infected patients with comparable CMV disease (19). Factors other than the circulating virus load (such as graft-versus-host disease) are probably also important in the pathogenesis of CMV pneumonitis in this population and must be considered when therapeutic decisions are made. As a result, a low blood viral load threshold probably needs to be selected in pre-emptive protocols after BMT (20). Nevertheless, a high CMV load in plasma during the first three months after BMT (particularly $10^{4}$ copies/mL or greater) was recently associated with late development (after day 120) of CMV disease (21).

Another potential use of quantitative PCR consists of monitoring the CMV burden at the site of disease where active viral replication should take place. Such an approach may be appropriate particularly for some types of CMV disease associated with a lower blood viral load, such as CMV encephalitis/myelitis in AIDS patients and CMV pneumonitis in BMT recipients. In that regard, Shinkai et al (22) reported a higher viral load in AIDS patients with polyradiculopathy compared with those with CMV encephalitis (median 4632 versus 612 copies/ $\mu \mathrm{L}$ of CSF). Arribas et al (23) also found a correlation between the viral load in CSF and disease outcome with patients having more than $10^{3}$ copies $/ 8 \mu \mathrm{L}$ of CSF experiencing more severe disease. We also demonstrated the important role of CMV in the pathogenesis of CMV pneumonitis by performing a quantitative analysis of the CMV DNA load in bronchoalveolar lavage (BAL) cells of immunocompromised patients (24). We found more than a $2 \log _{10}$ difference in the amounts of CMV DNA in BAL cells between patients with asymptomatic viral shedding and those with definite CMV pneumonia as defined by the presence of typical intranuclear viral inclusions in lung biopsies or BAL cells.

Quantitative CMV PCR assays have been used recently to monitor antiviral therapy in patients with established CMV disease. Roberts et al (16) estimated that CMV DNA levels declined exponentially with ganciclovir treatment, with an average half-life of 3.3 days. Our group also reported that a 10-day course of induction therapy with intravenous ganciclovir resulted in a 1.5 to $2.0 \log _{10}$ decrease in the blood CMV DNA load in SOT recipients and AIDS patients (19). In contrast, the viral load reduction after induction therapy was much smaller (about $1.0 \log _{10}$ ) in BMT recipients with CMV disease. Foscarnet therapy for 10 days has also been shown to decrease the levels of CMV DNA by more than $1 \log _{10}(20,328$ to 622 copies/ $1.5 \times 10^{5}$ PMNLS) in AIDS patients with asymptomatic CMV viremia (25). It is of more interest that rising levels of CMV DNA in the blood during antiviral treatment can help predict disease recurrence and the emergence of drug-resistant CMV strains in HIV-infected patients (26). Our group was the first to report a correlation between increasing CMV DNA levels in PMNL during therapy and the detection of specific CMV UL97 mutations conferring ganciclovir resistance in the same samples (27). We subsequently reported that plasma could be substituted for PMNL to detect UL97 mutations and predict drug failure (28). An example of a longitudinal analysis of the CMV viral load in an AIDS patient with CMV retinitis and subsequent emergence of a ganciclovir-resistant strain is shown in Figure 1.

In summary, several longitudinal, natural history studies have established PCR breakpoints for CMV disease in different clinical settings. However, there is a lack of randomized, controlled studies that validate the concept of using the CMV load in pre-emptive strategies. Many questions, such as the following, remain unanswered. Which is the best type of sample to use for monitoring: PMNLs versus plasma? What is the best interval for $\mathrm{CMV}$ monitoring? What is the role of other viral or host factors in the development of CMV disease? In addition, multi-institutional quality control programs are urgently needed to standardize and validate PCR protocols.

\section{EPSTEIN-BARR VIRUS LOAD}

Epstein-Barr virus (EBV) is one of the most common and widely disseminated human viruses. It is the causative agent of infectious mononucleosis and has been associated strongly with two malignancies: Burkitt's lymphoma and nasopharyngeal carcinoma. More recently, it has been implicated in the etiology of B cell lymphomas in immunocompromised patients, patients with Hodgkin's disease, oral hairy leukoplakia and post-transplant lymphoproliferative disorders (PTLD). EBV infects B cells and epithelial cells. In general, infection of B lymphocytes is latent, whereas active replication (lytic cycle) can take place in epithelial cells of the oropharynx.

Quantitative EBV PCR has been used mainly in the context of PTLD. This syndrome may vary from infectious mono- 


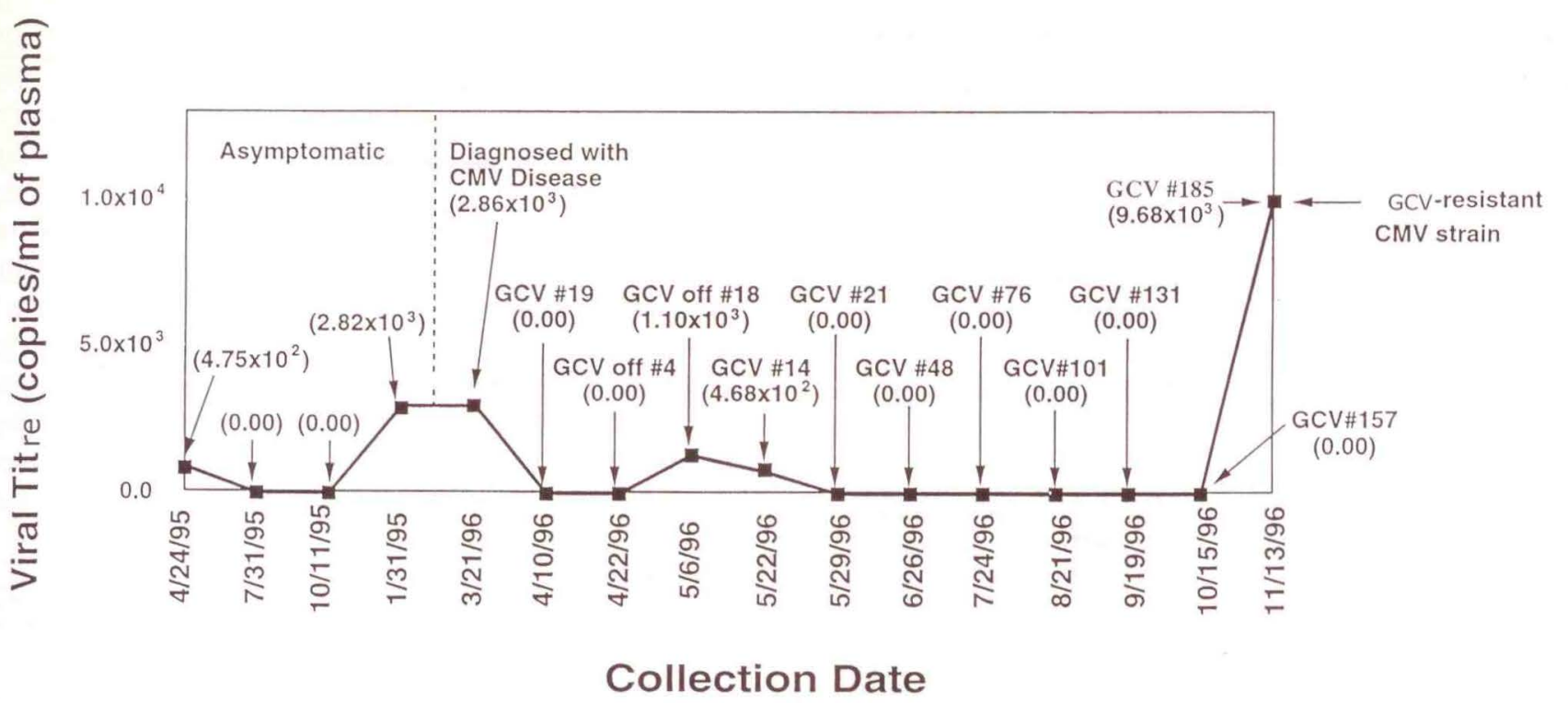

Figure 1) Longitudinal cytomegalovirus (CMV) DNA load analysis in plasma from a patient with human immunodeficiency virus. The viral titre, as determined by the Amplicor Monitor CMV Test (Roche Diagnostic, New Jersey) was determined over time in an HIV-infected patient. The time of diagnosis of CMV retinitis, the number of days of antiviral therapy and the viral titre (in parentheses) are indicated by arrows. On November 13, 1996, a blood CMV isolate was found to be resistant to ganciclovir ( $50 \%$ inhibitory concentration $10.8 \mu \mathrm{M}$ ) due to a UL97 mutation at codon 594 (Ala $($ Val). GCV Ganciclovir

nucleosis-like illness to solid localized tumours and is fatal in about $70 \%$ of cases (29). Some investigators have provided evidence for an association between high copy numbers of EBV in the peripheral blood and PTLD. Rowe et al (30) showed that the blood viral burden was significantly higher in paediatric transplant patients with PTLD (4000 copies $/ 10^{5}$ lymphocytes) compared with transplant patients without PTLD (fewer than eight copies) and in healthy seropositive individuals (fewer than 0.1 copies). Furthermore, in that study, 13 of 14 (92.8\%) patients with PTLD had greater than 500 copies $/ 10^{5}$ lymphocytes compared with none of the 12 transplant recipients without PTLD. The importance of the EBV DNA load in that context has been confirmed by other investigators, and viral load thresholds have been adopted at some transplant centres for enacting pre-emptive therapy with ganciclovir and cytogam $(31,32)$.

There is also mounting evidence that the presence of cellfree EBV DNA may be a good marker of active viral infection similar to the situation reported for CMV. Indeed, the concentration of EBV DNA in plasma was shown to correlate with the clinical status of patients with infectious mononucleosis (33). The amounts of EBV DNA in oropharyngeal cells also seem to be higher in primary versus reactivation infection and in patients with PTLD versus those without PTLD (34).

Although the EBV viral load seems to be an important factor in the pathogenesis of PTLD, several questions remain to be answered before routine EBV monitoring after transplantation can be recommended. These include the following. Is it advisable to monitor both seronegative recipients (the group at highest risk) and seropositive patients? What is the optimal threshold value for enacting pre-emptive therapy or reducing immunosuppression? Should investigators use a quantitative PCR assay based on leukocytes or a qualitative assay based on plasma for patient monitoring? Another important point concerns the effects of antiherpes agents on the EBV DNA load in blood or oropharyngeal cells. A recent preliminary report indicated no immediate effects of foscarnet on the EBV DNA load in the plasma of HIV-infected patients, although more detailed studies are needed on this aspect (35).

\section{HUMAN HERPESVIRUS 8 LOAD}

Human herpesvirus (HHV)-8, also known as Kaposi's sarcoma (KS)-associated herpesvirus, is a new member of the gamma Herpesvirinae subfamily discovered in 1994 by Chang et al (36). This virus has been associated with AIDS- and nonAIDS-related KS, multicentric Castleman's disease and body cavity-based lymphomas (37-39). Viral DNA has been detected in numerous body fluids, including blood (especially B lymphocytes), semen and saliva. Specific HHV-8 DNA sequences have been found in more than $95 \%$ of KS lesions from both HIV-positive and HIV-negative persons, in $20 \%$ to $71 \%$ of peripheral blood leukocytes (PBL) from HIV-infected patients with $\mathrm{KS}$, and in 0 to $11 \%$ of PBL from HIV-infected patients without KS $(40,41)$.

Recent quantitative PCR studies have provided some insights into the pathogenesis of KS and the relationship between HHV-8 and KS. Using semiquantitative PCR, Mendez et al (42) measured the intratumoral HHV-8 load in 12 patients previously diagnosed with KS by histopathological examination. They found higher levels of HHV-8 DNA in patients with 
TABLE 4

Clinical impact of quantitative assays for human herpesviruses (HHV)

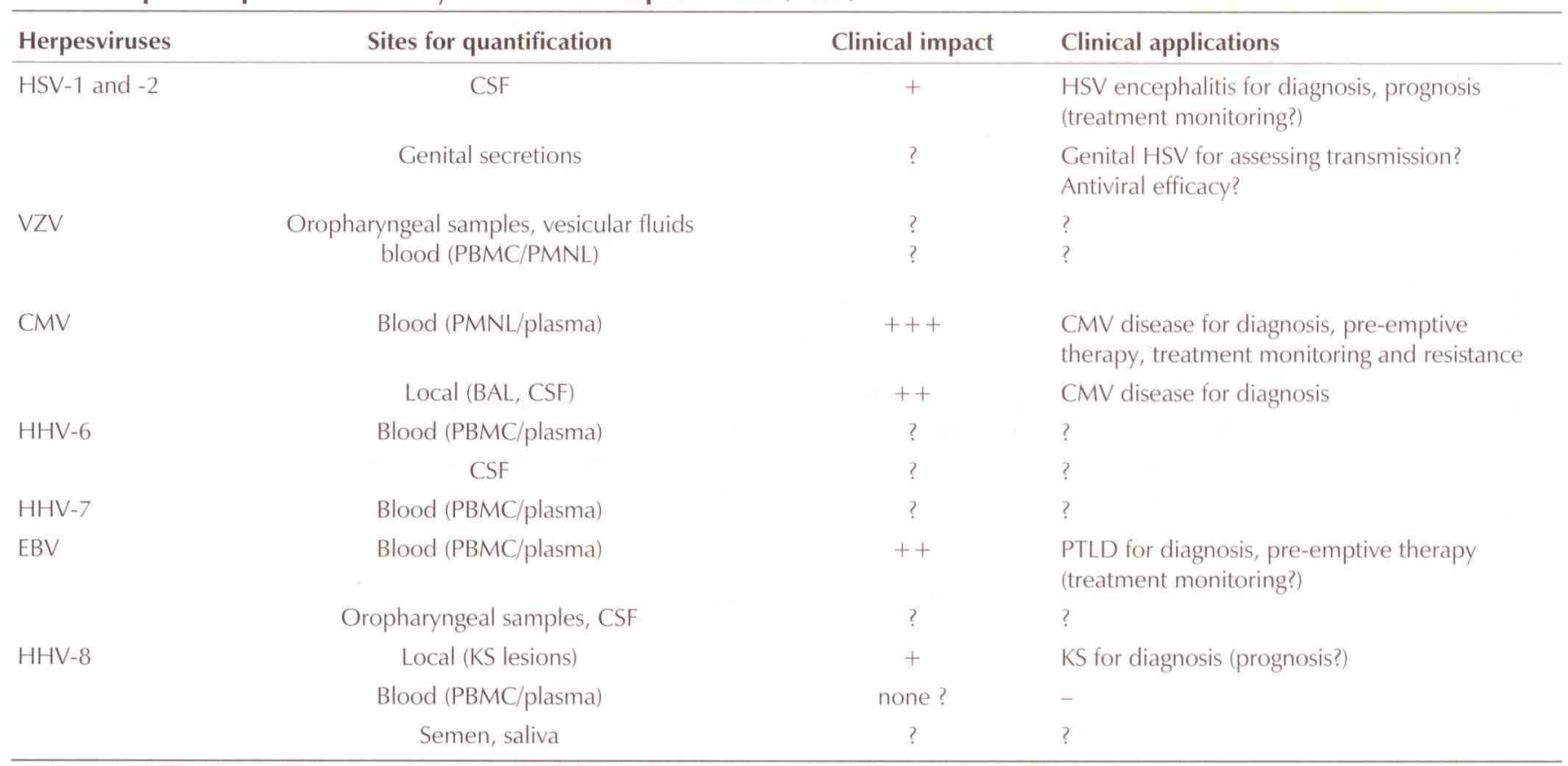

BAL Bronchoalveolar lavage; CMV Cytomegalovirus; CSF Cerebrospinal fluid; EBV Epstein-Barr virus; HSV Herpes simplex virus; KS Kaposi's sarcoma; PBMC Peripheral blood mononuclear cell; PMNL Polymorphonuclear leukocyte; PTLD Post-transplant lymphoproliferative disorders; VZV Varicella-zoster virus

multicentric and visceral involvement than in patients with localized disease. In addition, in subjects with localized skin disease, the nodular stage was associated with higher levels of HHV-8 DNA than with the patch or plaque stages. Recently, Koelle et al (43) detected HHV-8 DNA sequences in saliva samples from $75 \%$ of HIV-seropositive patients with KS. However, in that study, the levels of salivary HHV-8 DNA were not associated with the presence of oral KS lesions. In another study, quantitative PCR for HHV-8 was performed on DNA extracted from blood samples collected from a renal transplant patient diagnosed with KS eight months after transplantation (44). This report showed that the peak HHV-8 viral load was observed one week after KS developed and that a rapid decrease of the viral burden followed the termination of therapy with immunosuppressive drugs.

We designed a reproducible quantitative-competitive PCR assay for HHV-8 to determine the number of viral copies in PBL samples from a Canadian cohort of HIV-seropositive individuals with low CD4 T cell counts $\left(250 \times 10^{6} / \mathrm{L}\right)$ with or without KS (45). We initially showed that HHV-8 DNA sequences were detectable in 12 of 29 (41\%) of PBL from Canadian AIDS patients with KS compared with four of 43 (9.3\%) from those without KS $(P=0.003)$. However, the peak HHV-8 DNA load in PCR-positive patients with KS (mean 425 copies/0.2 $\mu \mathrm{g}$ of PBL DNA) did not significantly differ from the load found in the PCR-positive patients without KS (mean 218 copies). We then sought to determine whether common anti-CMV drugs (eg, ganciclovir and foscarnet) had any in vivo effects on the circulating HHV-8 DNA burden (45). Previous in vitro studies had demonstrated relative HHV-8 susceptibility to ganciclovir
(50\% inhibitory concentration $\left[\mathrm{IC}_{50}\right]$ value of about $5 \mu \mathrm{M}$ ) and foscarnet ( $\mathrm{IC}_{50}$ value of about $\left.100 \mu \mathrm{M}\right)(46,47)$. The administration of either intravenous ganciclovir or foscarnet in our patients with both CMV disease and KS induced a significant and rapid decrease in the blood CMV DNA load but not in the HHV-8 viral burden. From our results, we hypothesize that most of the HHV- 8 genome detected in the blood of AIDS patients with KS is probably from latent, nonreplicative viruses.

In summary, it appears that unlike the situation with CMV, the measure of the circulating HHV-8 DNA load is not a reliable surrogate marker for disease activity (ie, KS) or response to antiviral therapy. However, larger prospective studies are needed to confirm these preliminary observations. Many other important questions concerning the HHV-8 DNA load remain unanswered. For example, are there other acute or chronic forms of HHV-8 infection in which active replication takes place and where quantitative PCR assays can be of interest? Also, can active antiviral drugs be beneficial in blocking viral replication at an early stage and preventing the development of KS in HIV-infected patients?

\section{OTHER HERPESVIRUSES AND CONCLUSIVE REMARKS}

There are far less data concerning the role of quantitative PCR for the clinical management of other human herpesviruses (VZV and HHV-6 and HHV-7). Consequently, they will not be discussed further in this review. It should be noted, however, that HHV-6 has been recently linked to many posttransplantation disorders, including infectious complications (pneumonitis, encephalitis) and organ rejection/graft-ver- 
sus-host disease $(48,49)$. Quantitative analysis of the HHV-6 DNA load should shed some light on the causative role of this virus in posttransplantation complications.

In conclusion, the relevance of measuring the CMV load and, to some extent, the EBV load, has been well demonstrated for the clinical situations listed in Table 4. Debate continues on the clinical utility of performing quantitative determination of the HSV and HHV-8 viral loads. There is a paucity of data at the present time to evaluate the impact of quantifying the VZV, HHV-6 and HHV-7 DNA burdens. It is hoped that more standardized and rapid detection procedures of amplified viral products using realtime PCR (COBAS TaqMan, Roche Molecular Systems, New Jersey), for example, will allow more widespread use of these molecular methods in the future.

ACKNOWLEDGEMENTS: The author thanks the many collaborators for their work on CMV and HHV-8, including Drs MG Bergeron, H Senay, S Trottier, L Côté, A Martel and G Murray (Québec City); Drs E Toma, R Lalonde and JP Routy (Montréal); and Drs MC Jordan, A Erice and HH Balfour Jr (Minneapolis, Minnesota). The author also acknowledges the excellent work of his research assistants: J Handfield, N Goyette and A Gaudreau. Grant support was from the Medical Research Council of Canada (grant no MT-13924), Canadian Foundation for AIDS Research, and the Fonds de la Recherche en Santé du Québec (grant no 96007). Dr Guy Boivin is a Research Scholar of the Medical Research Council of Canada.

\section{REFERENCES}

1. Strauss SE. Introduction to Herpesviridae. In: Mandell GL, Bennett JE, Dolin R, eds. Principles and Practices of Infectious Diseases, 4th edn. New York: Churchill Linvingstone, 1995:1330-6.

2. Kessler HH, Pierer K, Weber B, et al. Detection of herpes simplex virus DNA from cerebrospinal fluid by PCR and a rapid, nonradioactive hybridization technique. J Clin Microbiol 1994:32:1881-6.

3. Lakeman FD, Whitley RJ. Diagnosis of herpes simplex encephalitis: application of polymerase chain reaction to cerebrospinal fluid from brain-biopsied patients and correlation with disease. J Infect Dis 1995; 171:857-63.

4. Rowley AH, Whitley RJ, Lakeman FD, Wolinsky SM. Rapid detection of herpes-simplex-virus DNA in cerebrospinal fluid of patients with herpes simplex encephalitis. Lancet 1990;335:440-1.

5. Domingues RB, Lakeman FD, Mayo MS, Whitley RJ. Application of competitive PCR to cerebrospinal fluid samples from patients with herpes simplex encephalitis. J Clin Microbiol 1998;36:2229-34.

6. Wildemann B, Ehrhart K, Storch-Hagenlocher B, et al. Quantitation of herpes simplex virus type 1 DNA in cells of cerebrospinal fluid of patients with herpes simplex virus encephalitis. Neurology 1997;48:1341-6.

7. Revello MG, Baldanti F, Sarasini A, Zella D, Zavattoni M, Gerna G. Quantitation of herpes simplex virus DNA in cerebrospinal fluid of patients with herpes simplex encephalitis by the polymerase chain reaction. Clin Diagn Virol 1997; 7:183-91.

8. Hobson A, Wald A, Wright N, Corey L. Evaluation of a quantitative competitive PCR assay for measuring herpes simplex virus DNA content in genital tract secretions. J Clin Microbiol 1997;35:548-52.

9. Meyers JD, Ljungman P, Fisher LD. Cytomegalovirus excretion as a predictor of cytomegalovirus disease after marrow transplantation: importance of cytomegalovirus viremia. J Infect Dis 1990;162:373-80.

10. Salmon D, Lacassin F, Harzic M, et al. Predictive value of cytomegalovirus viraemia for the occurrence of CMV organ involvement in AIDS. J Med Virol 1990;32:160-3.
11. Bowen EF, Sabin CA, Wilson P, et al. Cytomegalovirus (CMV) viraemia detected by polymerase chain reaction identifies a group of HIV-positive patients at high risk of CMV disease. AIDS 1997;11:889-93.

12. Spector SA, Wong R, Hsia K, Pilcher M, Stempien MJ. Plasma cytomegalovirus (CMV) DNA load predicts CMV disease and survival in AIDS patients. J Clin Invest 1998;101:497-502.

13. Boivin G, Handfield J, Murray G, et al. Quantitation of cytomegalovirus (CMV) DNA in leukocytes of human immunodeficiency virus-infected subjects with and without CMV disease by using PCR and the SHARP Signal Detection System. J Clin Microbiol 1997;35:525-6.

14. Rasmussen L, Morris S, Zipeto D, et al. Quantitation of human cytomegalovirus DNA from peripheral blood cells of human immunodeficiency virus-infected patients could predict cytomegalovirus retinitis. J Infect Dis 1995;171:177-82.

15. Boivin G, Handfield J, Toma E, Murray G, Lalonde R, Bergeron MG. Comparative evaluation of the cytomegalovirus DNA load in polymorphonuclear leukocytes and plasma of human immunodeficiency virus-infected subjects. J Infect Dis $1998 ; 177: 355-60$.

16. Roberts TC, Brennan DC, Buller RS, et al. Quantitative polymerase chain reaction to predict occurrence of symptomatic cytomegalovirus infection and assess response to ganciclovir therapy in renal transplant recipients. J Infect Dis 1998; 178:626-35.

17. Cope AV, Sabin C, Burroughs A, Rolles K, Griffiths PD, Emery VC. Interrelationships among quantity of human cytomegalovirus (HCMV) DNA in blood, donor-recipient serostatus, and administration of methylprednisolone as risk factors for HCMV disease following liver transplantation. J Infect Dis 1997; 176:1484-90.

18. Toyoda M, Carlos JB, Galera OA, et al. Correlation of cytomegalovirus DNA levels with response to antiviral therapy in cardiac and renal allograft recipients. Transplantation 1997;63:957-63.

19. Boivin G, Quirk MR, Kringstad BA, Germain M, Jordan MC. Early effects of ganciclovir therapy on the quantity of cytomegalovirus DNA in leukocytes of immunocompromised patients. Antimicrob Agents Chemother 1997;41:860-2.

20. Boeckh M, Gooley TA, Myerson D, Cunningham T, Schoch G, Bowden RA. Cytomegalovirus pp65 antigenemia-guided early treatment with ganciclovir versus ganciclovir at engraftment after allogeneic marrow transplantation: a randomized double-blind study. Blood 1996;88:4063-71.

21. Zaia JA, Gallez-Hawkins GM, Tegtmeier BR, et al. Late cytomegalovirus disease in marrow transplantation is predicted by virus load in plasma. J Infect Dis 1997;176:782-5.

22. Shinkai M, Spector SA. Quantitation of human cytomegalovirus (HCMV) DNA in cerebrospinal fluid by competitive PCR in AIDS patients with different HCMV central nervous system diseases. Scand J Infect Dis 1995;27:559-61.

23. Arribas JR, Clifford DB, Fichtenbaum CJ, Commins DL, Powderly WG, Storch GA. Level of cytomegalovirus (CMV) DNA in cerebrospinal fluid of subjects with AIDS and CMV infection of the central nervous system. J Infect Dis 1995;172:527-31.

24. Boivin G, Olson CA, Quirk MR, Kringstad B, Hertz MI, Jordan MC. Quantitation of cytomegalovirus DNA and characterization of viral gene expression in bronchoalveolar cells of infected patients with and without pneumonitis. J Infect Dis 1996;173:1304-12.

25. Balfour HH Jr, Fletcher CV, Erice A, et al. Effect of foscarnet on quantities of cytomegalovirus and human immunodeficiency virus in blood of persons with AIDS. Antimicrob Agents Chemother 1996;40:2721-6.

26. Bowen EF, Wilson P, Cope A, et al. Cytomegalovirus retinitis in AIDS patients: influence of cytomegaloviral load on response to ganciclovir, time to recurrence and survival. AIDS 1996;10:1515-20.

27. Boivin G, Chou S, Quirk MR, Erice A, Jordan MC. Detection of ganciclovir resistance mutations and quantitation of cytomegalovirus (CMV) DNA in leukocytes of patients with fatal disseminated CMV disease. J Infect Dis 1996;173:523-8.

28. Boivin G, Gilbert C, Morisette M, Handfield J, Goyette N, Bergeron MG. A case of ganciclovir-resistant cytomegalovirus (CMV) retinitis in a patient with AIDS: longitudinal analysis of 
CMV viral load and viral mutations in blood compartments. AIDS 1997; 11:867-73.

29. Thomas JA, Crawford DH, Burke M. Clinicopathologic implications of Epstein-Barr virus related B cell lymphoma in immunocompromised patients. J Clin Pathol 1995;48:287-90.

30. Rowe DT, Qu L, Reyes J, et al. Use of quantitative competitive PCR to measure Epstein-Barr virus genome load in the peripheral blood of pediatric transplant patients with lymphoproliferative disorders. J Clin Microbiol 1997;35:1612-5.

31. Green M, Reyes J, Jabbour N, et al. Use of quantitative PCR to predict onset of Epstein-Barr viral infection and post-transplant lymphoproliferative disease after intestinal transplantation in children. Transplant Proc 1996;28:2759-60.

32. Bai X, Hosler G, Rogers BB, Dawson DB, Scheuermann RH. Quantitative polymerase chain reaction for human herpesvirus diagnosis and measurement of Epstein-Barr virus burden in posttransplant lymphoproliferative disorder. Clin Chem 1997;43:1843-9.

33. Yamamoto $\mathrm{M}$, Kimura $\mathrm{H}$, Hironaka $\mathrm{T}$, et al. Detection and quantification of virus DNA in plasma of patients with Epstein-Barr virus-associated diseases. J Clin Microbiol 1995;33:1765-8.

34. Preiksaitis JK, Diaz-Mitoma F, Mirzayans F, Roberts S, Tyrrell DL. Quantitative oropharyngeal Epstein-Barr virus shedding in renal and cardiac transplant recipients: relationship to immunosuppressive therapy, serologic responses, and the risk of posttransplant lymphoproliferative disorder. J Infect Dis 1992;166:986-94.

35. Salmon-Ceron D, Seigneurin JM, Gerard L, et al. Assesment of the effect of foscarnet on Epstein-Barr virus in a randomized controlled trial in HIV-infected patients. 38th Interscience Conference on Antimicrobial Agents and Chemotherapy. San Diego, September 24 to September 27, 1998. (Abst H-39)

36. Chang Y, Cesarman E, Pessin MS, et al. Identification of herpesvirus-like DNA sequences in AIDS-associated Kaposi's sarcoma. Science 1994;266:1865-9.

37. Moore PS, Chang Y. Detection of herpesvirus-like DNA sequences in Kaposi's sarcoma in patients with and without HIV infection. N Engl J Med 1995;332:1181-5.

38. Soulier J, Grollet L, Oksenhendler E, et al. Kaposi's sarcoma-associated herpesvirus-like DNA sequences in multicentric Castleman's disease. Blood 1995;86:1276-80.

39. Cesarman E, Chang Y, Moore PS, Said JW, Knowles DM. Kaposi's sarcoma-associated herpesvirus-like DNA sequences in
AIDS-related body-cavity-based lymphomas. N Engl I Med 1995;332:1186-91.

40. Smith MS, Bloomer C, Horvat R, Goldstein E, Casparian JM, Chandran B. Detection of human herpesvirus 8 DNA in Kaposi's sarcoma lesions and peripheral blood of human immunodeficiency virus-positive patients and correlation with serologic measurements. J Infect Dis 1997; 176:84-93.

41. Whitby D, Howard MR, Tenant-Flowers M, et al. Detection of Kaposi sarcoma-associated herpesvirus in peripheral blood of HIV-infected individuals and progression to Kaposi's sarcoma. Lancet 1995;346:799-802.

42. Mendez JC, Procop GW, Espy MJ, Paya CV, Smith TF. Detection and semiquantitative analysis of human herpesvirus 8 DNA in specimens from patients with Kaposi's sarcoma. J Clin Microbiol 1998; 36:2220-2.

43. Koelle DM, Huang ML, Chandran B, Vieira J, Piepkorn M, Corey L. Frequent detection of Kaposi's sarcoma-associated herpesvirus (human herpesvirus 8) DNA in saliva of human immunodeficiency virus-infected men: clinical and immunologic correlates. J Infect Dis 1997; 176:94-102.

44. Lock MJ, Griffiths PD, Emery VC. Development of a quantitative competitive polymerase chain reaction for human herpesvirus 8 . J Virol Methods 1997;64:19-26.

45. Boivin G, Gaudreau A, Toma E, et al. Human herpesvirus 8 DNA load in leukocytes of human immunodeficiency virus-infected subjects: correlation with the presence of Kaposi's sarcoma and response to anti-cytomegalovirus therapy. Antimicrob Agents Chemother 1999;43:377-80.

46. Kedes DH, Ganem D. Sensitivity of Kaposi's sarcoma-associated herpesvirus replication to antiviral drugs. Implications for potential therapy. J Clin Invest 1997;99:2082-6.

47. Medveczky MM, Horvath E, Lund T, Medveczky PG. In vitro antiviral drug sensitivity of the Kaposi's sarcoma-associated herpesvirus. AIDS 1997;11:1327-32.

48. Carrigan DR, Drobyski WR, Russler SK, Tapper MA, Knox KK, Ash RC. Interstitial pneumonitis associated with human herpesvirus- 6 infection after marrow transplantation. Lancet 1991;338:147-9.

49. Dobryski WR, Knox KK, Majewski D, Carrigan DR. Brief report: Fatal encephalitis due to variant B human herpesvirus-6 infection in a bone marrow-transplant recipient. N Engl J Med 1994;330:1356-60. 


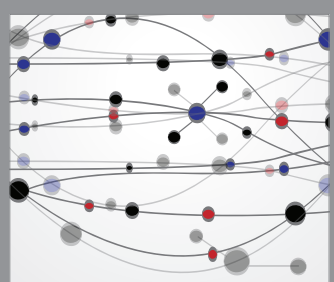

The Scientific World Journal
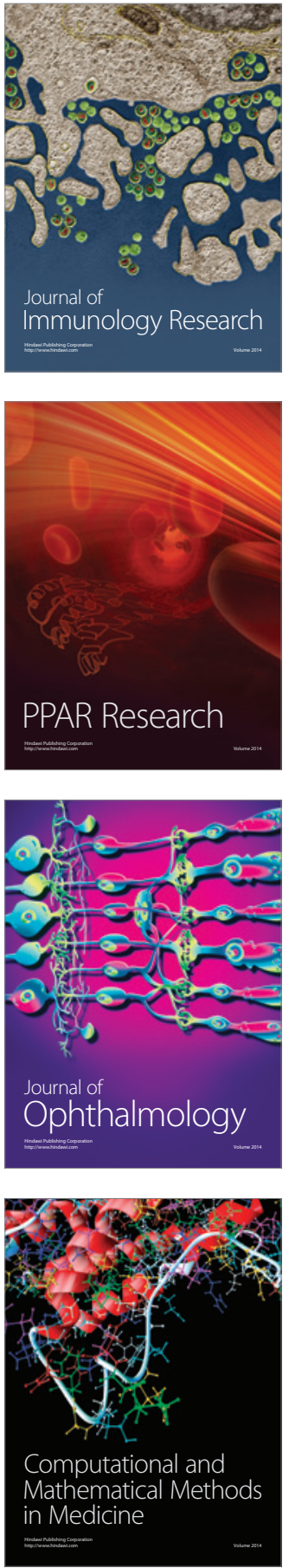

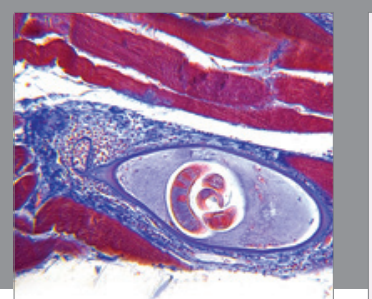

Gastroenterology Research and Practice

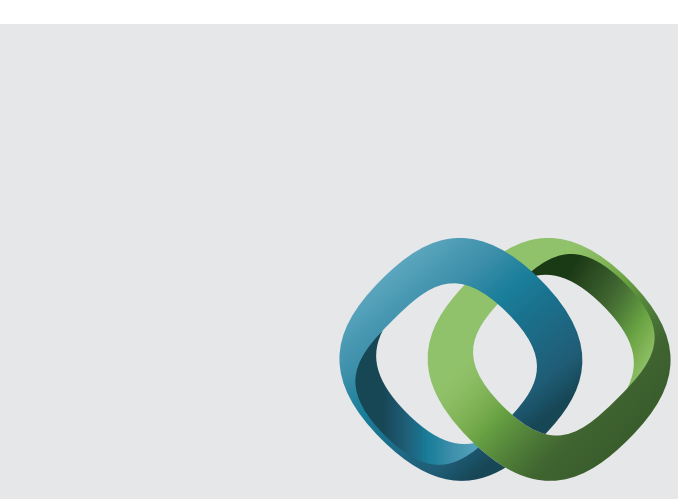

\section{Hindawi}

Submit your manuscripts at

http://www.hindawi.com
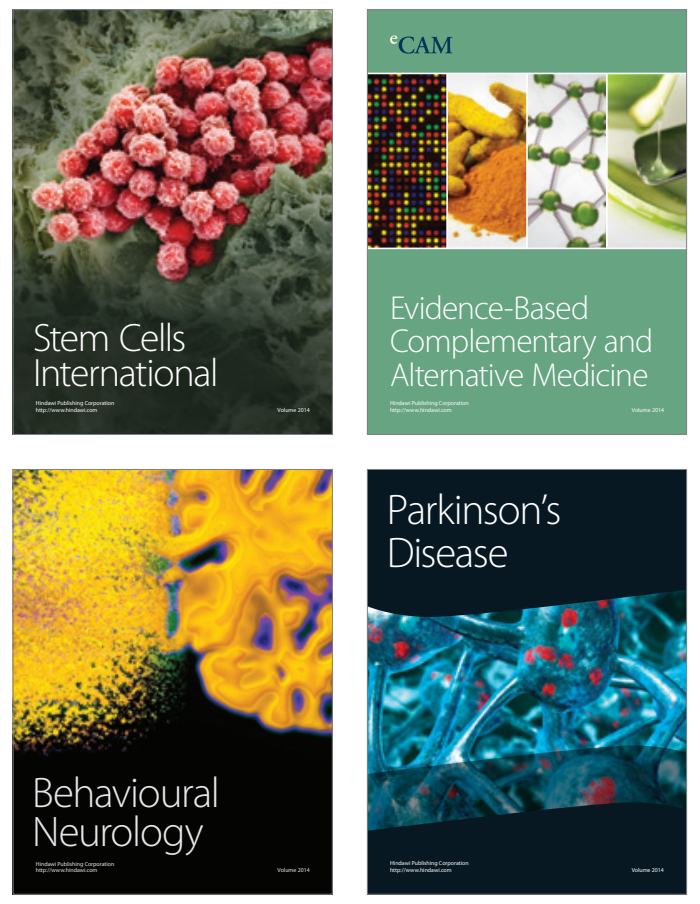
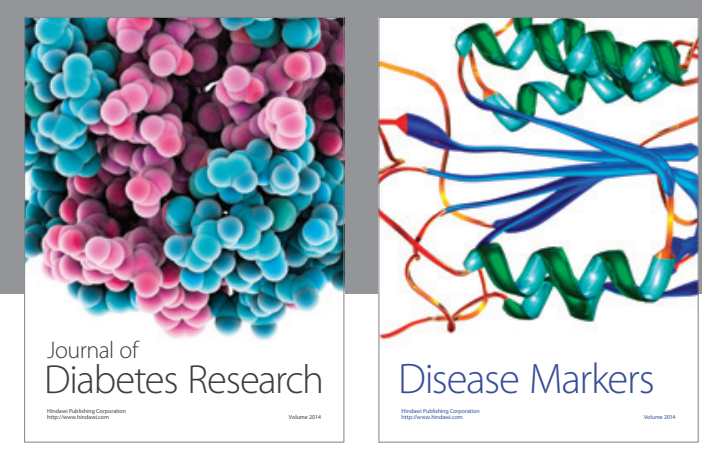

Disease Markers
